\title{
Tumor Necrosis Factor Receptor Superfamily Member 4
}

National Cancer Institute

\section{Source}

National Cancer Institute. Tumor Necrosis Factor Receptor Superfamily Member 4. NCI

Thesaurus. Code C94790.

Tumor necrosis factor receptor superfamily member 4 (277 aa, $29 \mathrm{kDa}$ ) is encoded by the human TNFRSF4 gene. This protein plays a role in signal transduction pathways that mediate apoptosis inhibition and inflammatory responses. 